\title{
STYRAX PAULHOUSEI (STYRACACEAE), A NEW SPECIES FROM HONDURAS
}

\author{
Peter W. Fritsch \\ Botanical Research Institute of Texas \\ 1700 University Drive \\ Fort Worth, Texas 76107, U.S.A. \\ pfritsch@brit.org
}

\author{
Caroline Whitefoord \\ The Herbarium \\ Natural History Museum \\ Cromwell Road \\ London SW7 5BD, U.K.
}

\author{
Daniel L. Kelly \\ Department of Botany \\ School of Natural Sciences \\ Trinity College \\ The University of Dublin \\ Dublin 2, IRELAND
}

\section{ABSTRACT}

Styrax paulhousei, a new species of Styrax L. series Valvatae Perkins from northwestern Honduras, is described and illustrated. It is similar to S. ramirezii Greenm. but differs in having fewer secondary leaf veins and larger corollas. The species is endemic to the Sierra del Merendón in the Department of Cortés and is categorized as vulnerable as based on IUCN Red List criteria. The discovery of this species brings the number of Styrax species native in Honduras to six.

\section{RESUMEN}

Se describe e ilustra Styrax paulhousei, especie nueva de Styrax L. series Valvatae Perkins, del noroeste de Honduras. Se parece a S. ramirezii Greenm., pero se diferencia de aquel por tener menos venas secundarias en la hoja y corolas más grandes. La especie es endémica de la Sierra del Merendón en el Departamento de Cortés y se clasifica como vulnerable según los criterios de la Lista Roja de la IUCN. El descubrimiento de esta especie eleva a seis el número de especies de Styrax nativas en Honduras.

KEY Words: Endemic, Honduras, IUCN Red List, new species, Styrax

\section{INTRODUCTION}

Founded in 1987, Cusuco National Park lies in the upper reaches of the Sierra del Merendón, a rugged mountain range in the northwest of Honduras; the core zone rises to the highest point at $2242 \mathrm{~m}$. This zone is largely forested, with a complex mixture of pine forest and broadleaf-dominated montane rain forest (cloud forest) and patches of elfin forest on the ridgetops. Significant logging has occurred in recent years within the western parts of the core zone. A preliminary account of the ecology of the park (Fundación Ecologista "Hector Rodrigo Pastor Fasquelle," The Nature Conservancy, \& Proyecto Ambiental para Centro América 1994) has been followed since 2003 by wide-ranging research under the aegis of Operation Wallacea, a U.K.-based educational charity. Work by the Operation Wallacea Forest Botany Team on the vegetation and flora has already led to the discovery of a tree genus new to science (Hondurodendron Ulloa et al., Aptandraceae/Olacaceae (Ulloa Ulloa et al. 2010), and two additional new plant species, i.e., the herb Calathea carolineae Kennedy (Marantaceae; Kennedy 2012) and the tree Sommera cusucoana Lorence et al. (Rubiaceae; Lorence et al. 2015). Descriptions of further new species are in preparation. All of these species are known from nowhere else but Cusuco National Park. The park is becoming recognized as a hotspot for biodiversity, not only for plants but also birds (Martin $\&$ Blackburn 2014), amphibians (Townsend 2008), and a range of invertebrate groups (e.g., Bravo et al. 2014; Rodrigues et al. 2017).

During field exploration of the region between 2004 and 2013, all expeditions in the months of JuneAugust, the third author encountered individuals of Styrax L. (Styracaceae) with an unusual combination of characters. On finding flowering material in March 2016, he sent a duplicate to the first author for identification. On careful examination of this material and in consultation with relevant taxonomic literature (Fritsch $1997,1999,2001,2004,2005,2009,2015)$, the first author confirmed that the specimen represents a species of this genus new to science, which is described and illustrated here. 


\section{TAXONOMIC TREATMENT}

Styrax paulhousei P.W. Fritsch \& D.L. Kelly, sp. nov. (Figs. 1-3). TYPe: HONDURAS. CoRTÉs: Sierra del Merendón, W of San Pedro Sula, near Río Cusuco, by Trail BC4, ca. 2075 m by trail W from "Base Camp"/Campamento Parque Nacional Cusuco, UTM 16P 0368417140 [corrected to $368551714150 ; 15.50131^{\circ} \mathrm{N}, 88.22553^{\circ} \mathrm{W}$ ], $1650 \mathrm{~m}, 31 \mathrm{Mar}$ 2016, D.L. Kelly, F. Fernandez, S. Hanley, P. O’Brian, \& C. Owens 16099 (HоLоTYPE: TEFH!; ISOTYPEs: BM!, BRIT!, MO!, TCD!).

Haec species Styraci ramirezii Greenm. simillima, sed ab eo nervis laminae utroque costae latere 7 vel 8, corollis longioribus, lobis corollae longioribus differt.

Tree, apparently evergreen, to ca. $22 \mathrm{~m}$ tall. Bark smooth. Young branchlets and petioles densely covered with dull ferrugineous stellate trichomes with \pm stiff straight arms. Leaves: petioles $9-12 \mathrm{~mm}$; leaf blades ovateelliptic, 8.4-12 $\times 3.6-5.3 \mathrm{~cm}, 2.2-2.5$ times as long as wide, chartaceous, abaxially with evenly scattered white or pale orange stellate trichomes with 10 to $12 \pm$ stiff straight arms to $1.3 \mathrm{~mm}$ (arms of trichomes near leaf surface much shorter), denser and larger on major veins and in leaf axils, adaxially glabrous except on major veins; midvein raised abaxially, impressed adaxially, secondary veins 7 or 8 on each side of midvein, tawny yellow, raised abaxially, slightly so adaxially, tertiary and quaternary veins raised abaxially (their surfaces easily visible through the pubescence) and adaxially; base subrounded to rounded, margin entire, planar, apex acute to slightly acuminate; leaf domatia present in axils of some secondary leaf veins, 1-1.3 mm, marsupiform, mostly obscured by pubescence. Inflorescences axillary and pseudoterminal, raceme-like, $3.5-4.3 \mathrm{~cm}$, each with 5 to 9 (to 10) flowers, rachis $9-10 \times 1-1.3 \mathrm{~mm}$, pedicels $8-10 \mathrm{~mm}$, rachis and pedicels densely covered with large orange stellate trichomes overtopping a base tomentum of small white stellate trichomes. Flowers 1.8-2.2 cm, hermaphroditic. Calyx cupuliform, 4.5-5 × 5.5-6 mm, outer surface densely covered to about $1 \mathrm{~mm}$ from margin with greenish white and more scattered pale orange stiff and straight-armed trichomes, trichomes at mid-calyx with arms to $1 \mathrm{~mm}$, within ca. $1 \mathrm{~mm}$ from margin these trichomes dissipating, thus revealing a base tomentum of minute white stellate trichomes that extends to the margin; calyx margin truncate between the 5 minute teeth, glandular toward inner (adaxial) side. Corolla white, 16-19 mm, petals connate ca. $3 \mathrm{~mm}$ beyond calyx margin; lobes 5, valvate in bud, spreading, linear-deltoid, 11-14 × 2.4-3 $\mathrm{mm}$, abaxially covered with flattened stellate trichomes. Stamens 10; stamen tube diverging from corolla at ca. $2 \mathrm{~mm}$, free portion ca. $3 \mathrm{~mm}$, dorsally covered with white stellate trichomes, ventrally glabrous; distinct portion of filaments 0.9-1.2 mm, of equal width throughout, margins slightly incurved, ventrally without auricles, ventral surface bearing dense white stellate trichomes with arms to ca. $0.3 \mathrm{~mm}$, the arms radiating from the central point in various directions, not primarily oriented parallel to the filament; anthers 4-4.5 × ca. 0.7 $\mathrm{mm}$, connectives nearly as wide as thecae in tangential view, glabrous; thecae linear, apically non-tapered, exceeding connective, sparsely stellate-pubescent at margins. Free portion of ovary conical, covered with greenish white stellate trichomes to ca. $1 \mathrm{~mm}$; style filiform, lower third densely hirsute, becoming glabrous at apex; stigma truncate, ca. $0.5 \mathrm{~mm}$ wide. Fruit unknown.

Distribution, Habitat, Ecology, and Common Names.-Styrax paulhousei is endemic to the Sierra del Merendón in the Department of Cortés, northwestern Honduras. Four individual trees were recorded, each at a separate location between 1592 and 1850 m elevation, growing as understory trees in primary or disturbed montane rain forest. They were observed growing on slopes and valley bottoms in acid, humus-rich soil (samples of the top $5 \mathrm{~cm}$ from two locations recorded loss-on-ignition 56-75\%, C/N ratio $17-19.5$, and $\mathrm{pH}$ 3.1-3.5). The forest canopy varied from conifer-dominated (Podocarpus oleifolius D. Don. or Pinus maximinoi H.E. Moore) to broadleaved with, e.g., Quercus spp. and Hieronyma oblonga Müll. Arg. Styrax paulhousei flowers in March. The flowers have a strong, sweet perfume resembling lily-of-the-valley (Convallaria majalis L.) and are clearly adapted to insect pollination. All specimens showed evidence of invertebrate herbivory despite the indumentum of stellate trichomes, which has been shown in other plant groups to interfere with feeding and colonization, especially by small insects such as aphids (Price et al. 2011). The evidence of leaf damage in S. paulhousei suggests that the species or genus may play host to a number of more or less specialized invertebrate herbivores. Damage included removal of significant portions of the leaves (from leaf margins and/or the inner parts of the lamina), fenestration (removal of mesophyll tissues, leaving only veins and cuticle), and leaf mines (tunnels in mesophyll caused by insect larvae). 


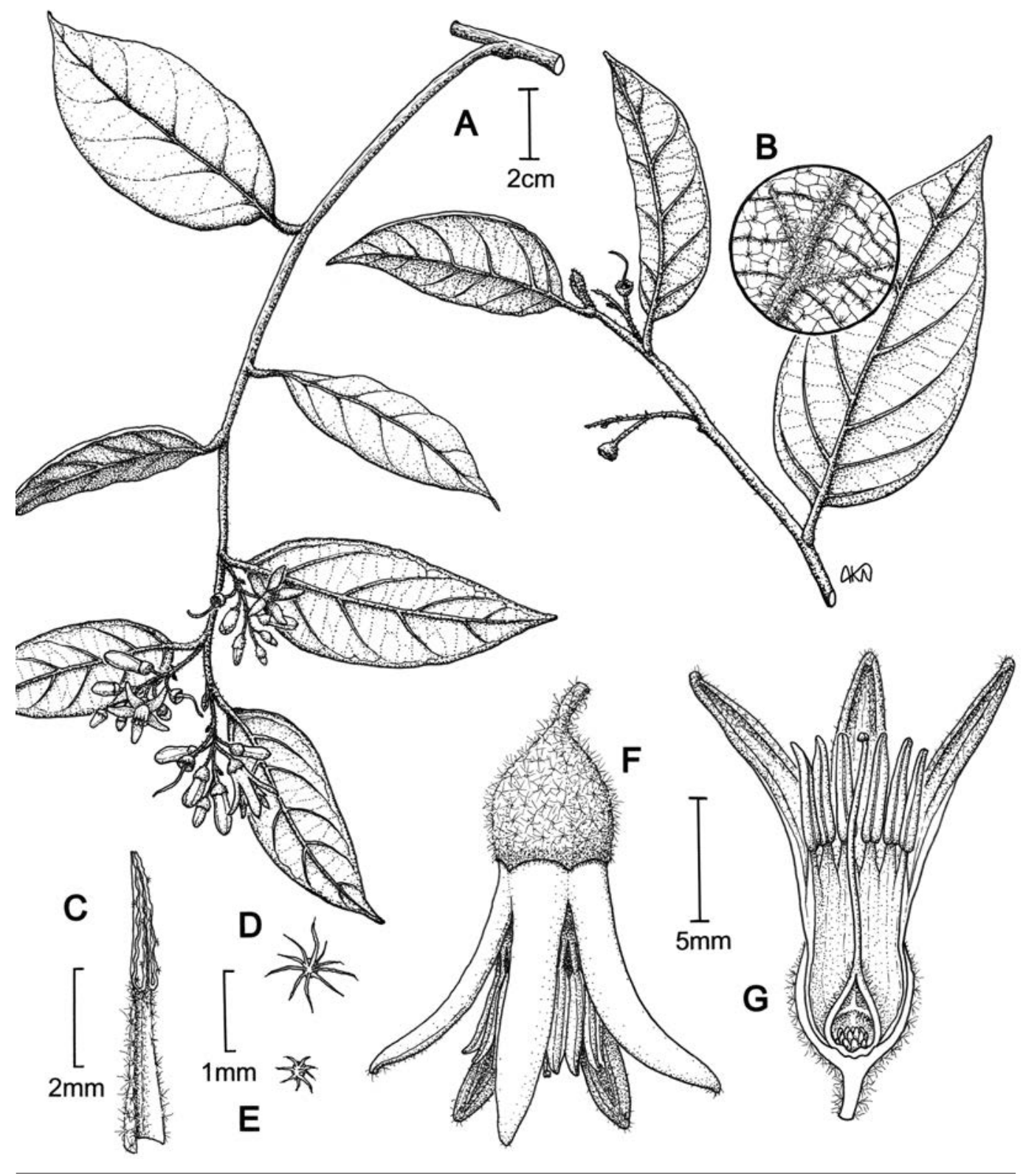

FIG. 1. Styrax paulhousei. A. flowering branchlet; B. branchlet with post-mature flowers (calyx and gynoecium); inset shows midvein and two secondary veins on abaxial leaf blade surface; C. stamen, including portion of filament free from corolla (connate portions of adjacent filaments not depicted); D, E. two trichomes from the abaxial surface of the leaf blade, showing variation in size; F. flower. G. flower sectioned longitudinally showing three of the five corolla lobes, six of the 10 stamens, and inside of ovary. A, C-G based on D.L. Kelly et al. 16099 (BRIT); B based on D.L. Kelly et al. 25/361 (BRIT).

The tree was identified by different guides as "Aguacatillo peludo" or "Nance de montaña." These names, however, are also applied locally to tree species in other families.

Etymology.-The new species is named in honor of the late Dr. Paul House (1961-2016), an authority on the plant life of Honduras. Born in Essex, in England, Paul spent most of his working life in Honduras. He carried out groundbreaking research in ethnobotany, principally in his work with the Tawakha people in the 


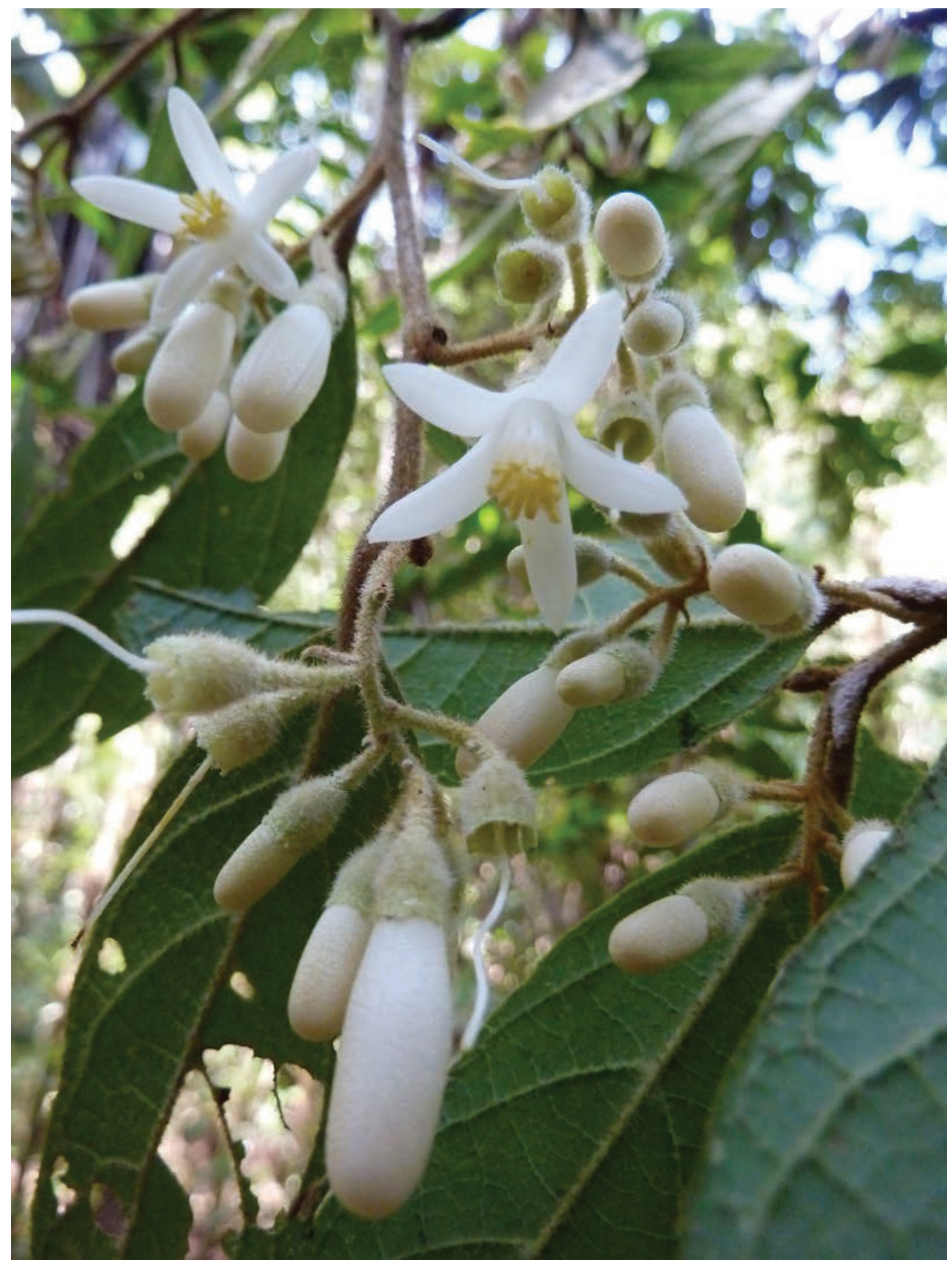

FIG. 2. Flowering branchlet of Styrax paulhousei. Photo by Sr. F. Fernandez. 


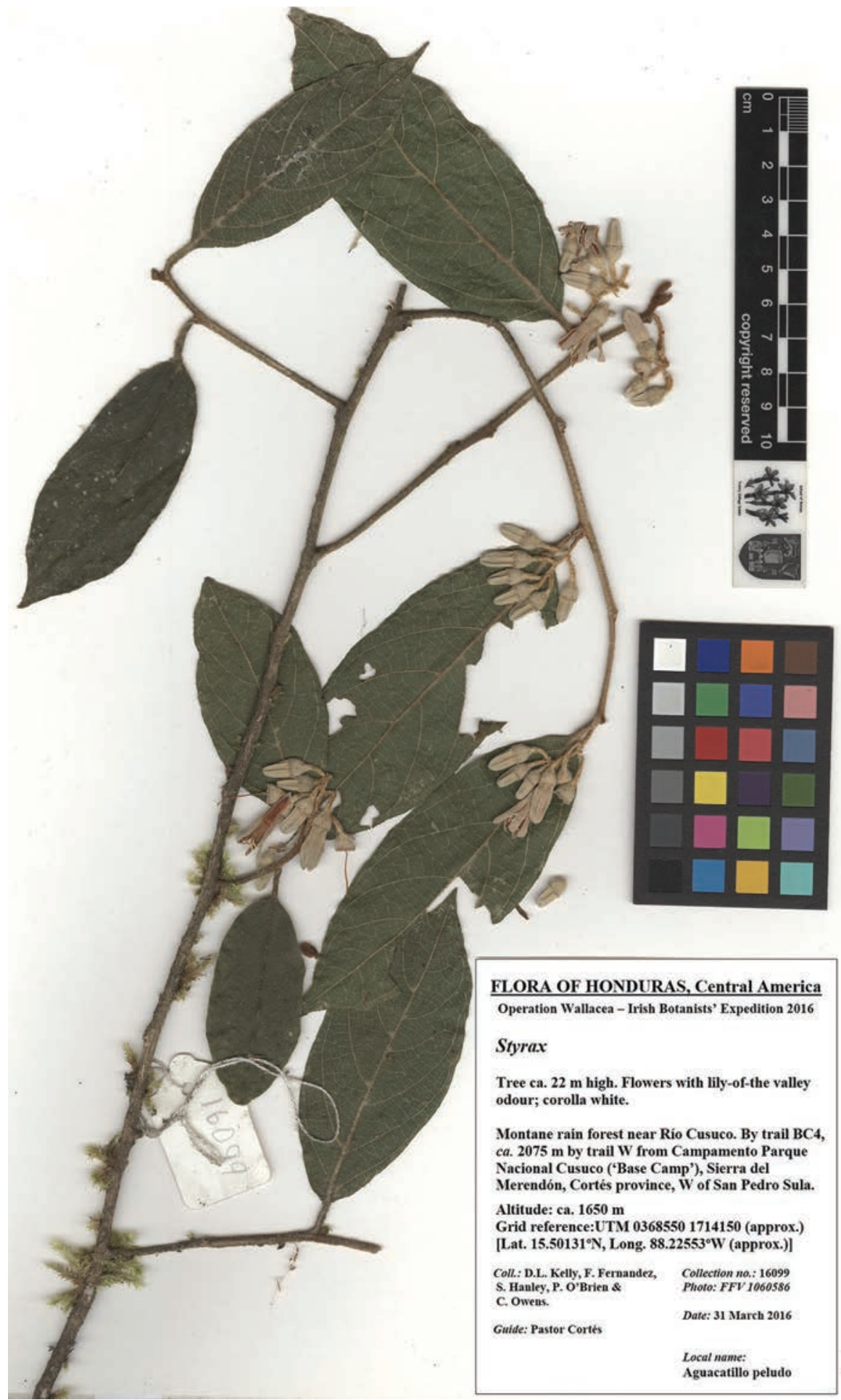

FIG. 3. Image of unmounted holotype specimen of Styrax paulhousei (TEFH). Scan by Ms. J. Stone. 
inaccessible Mosquitia region of eastern Honduras (Walker \& Barrance 2016). As professor in the School of Biology of the Universidad Nacional Autónoma de Honduras in Tegucigalpa, he made major contributions in teaching, research, and outreach. He was a tireless worker; one tangible part of his legacy is the University botanical garden, of which he was the founder. Paul was warmly supportive of the studies in Cusuco National Park that led to the discovery of this and other species.

Conservation Assessment.-Styrax paulhousei is known from only four collections in northwestern Honduras, each of which can be considered to represent a distinct population. These four populations are located within the boundaries of a protected area (Cusuco National Park) and declines in these populations are not evident. As calculated with the aid of GeoCAT (Bachman et al. 2011), the extent of occurrence is $1.85 \mathrm{~km}^{2}$ and the area of occupancy is $16 \mathrm{~km}^{2}$. In accordance with the International Union for Conservation of Nature Red List criteria (IUCN Standards and Petitions Subcommittee 2017), we categorize this species as Vulnerable (VU): D2.

Discussion.-Styrax paulhousei possesses a combination of characters that solidly places it within the exclusively Neotropical clade S. series Valvatae Perkins, i.e., an apparently evergreen habit, bases of young shoots without distinctly stalked trichomes, and a subcoriaceous corolla with valvate floral aestivation and straight sides (Wallnöfer 1997; Fritsch 1999, 2001). This series, with about 90 species, is endemic to the Neotropics and contains nearly all of the Neotropical species of Styrax. Although the fruit of S. paulhousei is unknown, by its placement in S. series Valvatae it can be expected to have a fleshy drupe and a smooth ellipsoid seed (Fritsch 1999).

In the key to the species of Styrax for western Texas, Mexico, and Mesoamerica in the treatment of Fritsch (1997), S. paulhousei would key to the Mexican endemic species S. ramirezii Greenm., specifically the form with stellate trichomes at mid-calyx (versus scales; p. 714, lead 19b). It can be distinguished from S. ramirezii by having only 7 or 8 secondary veins on each side of the leaf midvein (versus 10 to 15), and longer corollas (16-19 $\mathrm{mm}$ versus $8-14 \mathrm{~mm}$ ) and corolla lobes (11-14 mm versus 6-10 $\mathrm{mm}$ ). It is also distinct from S. ramirezii geographically: the populations of S. ramirezii nearest to the new species occur ca. $600 \mathrm{~km}$ to the west in far western Chiapas, Mexico, and those with the calyx of stellate trichomes are even farther away in Guerrero.

The discovery of Styrax paulhousei brings the number of Styrax species known in Honduras to six, along with S. argenteus C. Presl, S. conterminus Donn. Sm., S. glabrescens Benth., S. incarnatus P.W. Fritsch, and S. warscewiczii Perkins. The species is distinguished from all these species by the combination of its valvate corolla lobes in bud (imbricate in S. glabrescens), calyx with stellate-hirsute pubescence (versus scales in $S$. conterminus and $S$. warscewiczii), arms of the trichomes on the ventral side of the stamen filaments to $0.3 \mathrm{~mm}$ (versus up to 1-2 mm in S. argenteus), stamen connectives exceeding the thecae (versus the thecae exceeding the connective in S. argenteus), and the abaxial surface of the secondary and tertiary veins easily visible (versus obscured by the tomentum in S. incarnatus). Styrax glabrescens (D.L. Kelly 23/155 and CA5/SS5/21) and S. cf. argenteus (D.L. Kelly BC1/SS7/847, without flowers or fruit) have also been documented as occurring in the Sierra del Merendón.

Paratypes. HONDURAS. CoRtés: Cordillera del Merendón, Parque Nacional El Cusuco, W of San Pedro Sula, Plot 2, close to right bank of Río Cusuco, ca. 300 m NNE of "Base Camp"/Campamento Parque Nacional Cusuco 15.498849º , 88.212649W, 1592 m, 5 Jul 2004 , D.L. Kelly et al. 2/34 (BRIT!); Cordillera del Merendón, Parque Nacional El Cusuco, W of San Pedro Sula, Plot 25, ca. $19 \mathrm{~m}$ N of trail to Río Cantiles from big landslip area, $15.509787^{\circ} \mathrm{N}, 88.235328^{\circ} \mathrm{W}, 1850 \mathrm{~m}, 29 \mathrm{Jul}$ 2004, D.L. Kelly et al. 25/361 (TCD, TEFH!); Sierra del Merendón, Parque Nacional El Cusuco, W of San Pedro Sula, Plot CA5/SS6, $1500 \mathrm{~m}$ along the old hunter's trail to Agua Mansa, NW of Cantiles camp, $15.523243^{\circ} \mathrm{N}, 88.247127^{\circ} \mathrm{W}, 1811 \mathrm{~m}, 19 \mathrm{Jun} 2013$, D.L. Kelly \& A.C. Dietzsch CA5/SS6/485 (EAP!, TCD).

\section{ACKNOWLEDGMENTS}

This discovery is a product of fieldwork by successive members of the Operation Wallacea Forest Botany Team, culminating in the Irish Botanists' Expedition of 2016. We thank the co-leaders of the different expeditions, in particular Ms. Cordula Lennkh, Dr. Anke Dietzsch, Dr. Sven Batke, Ms. Sunniva Hanley, and Dr. Maria Long; the many volunteers involved; and the local guides, in particular Sr. Pastor Cortes and Sr. Danilo Alvarenga. We gratefully acknowledge the support and assistance of the Departamento de Biología, Universidad Nacional 
Autónoma de Honduras, in particular of Professor Cirilo Nelson, Dra. Lilian Ferrufino, and the late Professor Paul House. We also thank Ms. Amanda Neill for the splendid illustrations of the new species, Professor Jane Stout for assistance with assessment of herbivore damage, and José Linares and an anonymous reviewer for helpful comments on the manuscript. The fieldwork received financial and logistic support from Operation Wallacea, the Percy Sladen Memorial Fund, Trinity College Dublin Association \& Trust, and the Botany Department of Trinity College Dublin.

\section{REFERENCES}

Bachman, S., J. Moat, A.W. Hill, J. de la Torre, \& B. Scott. 2011. Supporting Red List threat assessments with GeoCAT: Geospatial conservation assessment tool. In: V. Smith \& L. Penev, eds. E-infrastructures for data publishing in biodiversity science. ZooKeys 150:117-126, ver. BETA. Available at http://geoCAT.kew.org. Accessed Nov 2016.

Bravo, F., D. Cordeiro, \& M. Joque. 2014. A new genus of Psychodinae (Diptera, Psychodidae) from phytotelmata in a Honduran cloud forest. Zootaxa 3841:418-428.

FRITSCH, P.W. 1997. A revision of Styrax (Styracaceae) for western Texas, Mexico, and Mesoamerica. Ann. Missouri Bot. Gard. 84:705-761. doi:10.2307/2992026

FRITSCH, P.W. 1999. Phylogeny of Styrax based on morphological characters, with implications for biogeography and infrageneric classification. Syst. Bot. 24:355-378. doi:10.2307/2419695

FRITSCH, P.W. 2001. Phylogeny and biogeography of the flowering plant genus Styrax (Styracaceae) based on chloroplast DNA restriction sites and DNA sequences of the internal transcribed spacer region. Molec. Phylogen. Evol. 19:387408. doi:10.1006/mpev.2001.0933

FRITSCH, P.W. 2004. Styracaceae. In: K. Kubitzki, ed. The families and genera of vascular plants. Springer-Verlag, Berlin, Germany. 6:434-442.

FRITSCH, P.W. 2005. A new species of Styrax (Styracaceae) from southern Mexico. Novon 15:421-424. Stable URL:http:// www.jstor.org/stable/3393486

FRITSCH, P.W. 2009. Styracaceae. In: G. Davidse et al., eds. Flora Mesoamericana. Universidad Nacional Autónoma de México, CdMex., Mexico. 4(1):617-620. Also available at http://http://www.tropicos.org/Project/FM. Accessed Jun 2018.

FRITSCH, P.W. 2015. Styrax peltatus (Styracaceae), a new species from Oaxaca, Mexico. J. Bot. Res. Inst. Texas 9:43-47.

Fundación Ecologista “Hector Rodrigo Pastor Fasquelle,"The Nature Conservancy, \& Proyecto Ambiental para Centro América. 1994. Evaluación ecológica rápida (EER). Parque Nacional “El Cusuco" y Cordillera del Merendon. Unpublished report.

IUCN Standards and Petitions Subcommittee. 2017. Guidelines for using the IUCN Red List categories and criteria, ver. 13. Available at http://cmsdocs.s3.amazonaws.com/RedListGuidelines.pdf. Accessed Nov 2016.

KENNEDY, H. 2012. Calathea carolineae (Marantaceae), a new species endemic to Honduras. J. Bot. Res. Inst. Texas 6:55-57.

LoRENCE, D.H., A.C. DietzSCH, \& D.L. KelLy. 2015. Sommera cusucoana, a new species of Rubiaceae from Honduras. PhytoKeys 57:1-9. doi:10.3897/phytokeys.57.5339

MARTIN, T.E. \& G.A. BLACKBURN. 2014. Conservation value of secondary forest habitats for endemic birds, a perspective from two widely separated tropical ecosystems. Ecography 37:250-260. doi:10.1111/j.1600-0587.2013.00234.

PricE, P.W., R.F. Denno, M.D. Eubanks, D.L. Finke, \& I. Kaplan. 2011. Insect ecology: Behavior, populations and communities. Cambridge University Press, Cambridge, U.K.

Rodrigues, H.M., J. Rivera, N. Reid, \& G.J. Svenson. 2017. An elusive Neotropical giant, Hondurantemna chespiritoi gen. $\mathrm{n}$. \& sp. n. (Antemninae, Mantidae): A new lineage of mantises exhibiting an ontogenetic change in cryptic strategy. ZooKeys 680:73-104.

TownsEND, J.H. 2008. Guide to the amphibians \& reptiles of Cusuco National Park, Honduras = Guâia de los anfibios y reptiles del Parque Nacional Cusuco, Honduras. Bibliomania!, Salt Lake City, Utah, U.S.A.

UlLoA ULLoA, C., D. NicKRENT, C. Whitefoord, \& D.L. KeLLy. 2010. Hondurodendron, a new monotypic genus of Aptandraceae from Honduras. Ann. Missouri Bot. Gard. 97:457-467. doi:10.3417/2009040

WaLkER, I. \& A. BARRANCE. 2016. Paul House obituary. Available at www.theguardian.com/science/2016/aug/23/paulhouse-obituary. Accessed Jun 2018.

WallnöFER, B. 1997. A revision of Styrax L. section Pamphilia (Mart. ex A.DC.) B. Walln. (Styracaceae). Ann. Naturhist. Mus. Wien, B, 99:681-720. Stable URL: http://www.jstor.org/stable/41767084 